\title{
Quality of Life People Living with HIV/AIDS and Its Characteristic from a VCT Centre in Indonesia
}

\author{
Sri Handayani ${ }^{1}$, Nita Yunianti Ratnasari ${ }^{1}$, Putri Halimu Husna ${ }^{1}$, Marni ${ }^{1}$, Tantut \\ Susanto $^{2^{*}}$
}

OPEN ACCESS

Citation: Sri Handayani, Nita Yunianti Ratnasari, Putri Halimu Husna, Marni, Tantut Susanto. Quality of Life People Living with HIV/AIDS and its characteristic from a VCT centre in Indonesia. Ethiop J Health Sci. 2019; 29(6):759.doi:http://dx.doi.org/10.4314/ej hs.v29 i6.13

Received: May 08, 2019

Accepted: August 18, 2019

Published: November 1, 2019

Copyright: (C2019 Handayani S, et al. This is an open access article distributed under the terms of the Creative Commons Attribution License, which permits unrestricted use, distribution, and reproduction in any medium, provided the original author and source are credited. Funding: No funding

Competing Interests: The authors declare that this manuscript was approved by all authors in its form and that no competing interest exists.

Affiliation and Correspondence: ${ }^{1}$ Akademi Keperawatan Giri Satria Husada, Wonogiri, Jawa Tengah, Indonesia

${ }^{2}$ Department of Community, Family, and Gerontic Health Nursing, Faculty of Nursing, University of Jember, Jember, Indonesia

*Email: tantut_s.psik@unej.ac.id

\section{ABSTRACT}

BACKGROUND: The quality of life (QoL) construct has also contributed to understanding the comprehension of factors involved in the existence of people infected by the HIV/AIDS. The objective of this study is to assess the quality of life (QoL) of people with HIV/AIDS (PLWHA) in Wonogiri District, Indonesia.

METHODS: A cross-sectional study was conducted from September to November 2017. Convenience sampling method was employed to recruit 39 people living with HIV/AIDS (PLWHA) at Voluntary Counselling and Testing (VCT) of Wonogiri, Indonesia. Research data were collected using a self-administered questionnaire of WHOQOL-HIV BREF. The data were further analysed using a $t-$ test and a Chi-square test, while linear regression was used to evaluate factors that correlate with the PLWHAs' quality of life.

RESULTS: The results showed that the gross mean score of social relationships domain is 13.59; psychological domain is 13.31; environment domain is 13.28; spiritual/personal beliefs domainis 13.15; physical domain is 13.10; and level of independence domain is 13.77. The symptom of HIV is associated with quality of life $(B=$ 7.611, $\beta=0.362, t=2,046, p$ value $=0.049$ ).

CONCLUSION: Healthcare provider should increase providerinitiated testing and counselling (PITC) to contracting group, high risk group, susceptible group, and the community. The PLWHA are recommended to actively participate in peer support groups (PSGs) so that they can improve their quality of life.

KEYWORDS: Quality of Life; PLWHA; WHOQOL-HIV BREF; HIV/AIDS; VCT

\section{INTRODUCTION}

Health refers to physical, mental and social well-being, not merely the absence of disease or infirmity (1). Therefore, measuring health and health care impacts must include not only improvements in disease frequency and severity, but also a well-being estimate. This can be done by evaluating the health care- related improvement in quality of life(1). Infection with human immunodeficiency virus (HIV) has been acknowledged as one of the of issues of human Health. Its impacts on

DOI: http://dx.doi.org/10.4314/ejhs.v29i6.13 
the society, culture, economy and politics contribute to an exceptionally serious human health problem (2). The negative image of becoming HIVpositive and the loss of self-esteem, friendship, support from the family, often at a young age around the moment of diagnosis, can trigger adjustment disorders that could have severe implications if persistent (3). PLWHA's responses to finding out that they were positively infected with HIV/AIDS can be classified into four stages. The first stage was the stage of loss marked by the feeling of not having a life passion, losing social status, losing independence, and fearing the future. The third stage is the rejection stage that is manifested by the depression / stress feeling because they cannot accept the reality. Anxiety is the fourth phase. PLWHA faces uncertainties in their future (4). Life quality is poor in most HIV patients $(63.7 \%)(5)$.

Recent study conducted in Brazil conclude that the quality of life of people living with HIV/AIDS presents losses, mainly in the financial and confidentiality areas, followed by general function of the body and satisfaction with life(6). The study conducted by Hipolito et.al shows relationship between the general perception of QoL and degree of satisfaction with health (7). The research which done by Surur et.al in Ethiopia presents that the all the domains of health related quality of life was found to be significantly associated with the World Health Organization clinical stage (8). QoL means had statistically significant correlation to CD4 count in physical health domain in HIV related characteristics (9).

Quality of Life (QoL) is the perceptions of individuals of their position in life in the context of the culture and value systems they live in and in relation to their objectives, expectations, standards and concerns (10). The importance of an overall subjective feeling of well-being pertaining to aspects of morale, happiness and satisfaction emphasizes in this definition. QOL, therefore, relates to both an adequacy of material circumstances as to how satisfied an individual is with these circumstances of life. The assessment of QOL aims to provide a comprehensive evaluation of the individual's well-being, which includes an assessment of their role functioning, community integration and personal adjustment through reflection on the sense of well-being and satisfaction experienced by people under their current life circumstances (8). HIV and AIDS do not only affect the physical well-being of PLWHA, but also the overall quality of life and the perceptions of various aspects of their lives and daily living. WHOQOL-HIV-BREF has been created and validated specifically for PLWHA by the World Health Organization; it assesses QoL on the basis of six domains (physical, psychological, level of independence, social interactions, environment and spiritual / belief), and involves HIV / AIDS-specific issues (5).

The QoL construct also contributes to the understanding of factors related to the existence of people infected by the Human Immunodeficiency Virus (HIV) and the disease which it causes, Acquired Immunodeficiency Syndrome (AIDS). HIV and AIDS have become key issues in the last three decades. More than 34 million people have been infected worldwide. These people are suffering from the disease and their quality of life (QoL) is decreasing (11). The identification of PLWHA's characteristics is needed to improve their quality of life. This study aims to discuss the quality of life of people with HIV/AIDS in Wonogiri District, Indonesia.

\section{MATERIALS AND METHODS}

Setting: The study was done in the VCT Centre of Sudiran Mangun Sumarso Hospital in Wonogiri. It is in the southern part of the Central Java in Indonesia. Wonogiri located at $134.3 \mathrm{~km}$ from the regional capital city, Semarang, and $580.4 \mathrm{~km}$ from Jakarta. The town had a total population of 80.618 , (39.622 males and 40.996 females). There was one public hospital, and 3 private hospital in the town. During this study piloted, there were a total of 372 HIV positive. However, of 372 people enrolled with HIV / AIDS were only 90 people who regularly took medication.

Study design and period: A cross-sectional study was conducted in Wonogiri from September to November 2017 to assess quality of life PLWHA.

Participants: The population of this study includes 90 people who were members of a peer support group in Voluntary Counselling and Testing (VCT) Sudiran Mangun Sumarso Hospital, Wonogiri. To achieve the objectives of the study, a convenience

DOI: http://x.doi.org/10.4314/ejhs.v29i6.13 
sampling of 39 People Living With HIV/AIDS (PLWHA) was defined, equivalent to $43.3 \%$ of the users registered in the service during the data collection period. The primary criterion for the inclusion of participants in the study was their presence on the days of medical care in the unit.

Instrument: Research data were collected using WHOQOL-HIV BREF, the shorter version of WHOQOLHIV. It is validated through an international field trial $(12)(13)(14)(15)$. Various instruments for measuring QOL have been developed and described, but very few studies had used the WHOQOL-HIV BREF instrument in people living with HIV and AIDS.

The WHOQOL-HIV BREF generated six domain scores, including: physical, psychological, level of independence, social relationships, environment and spirituality/religion/personal beliefs. The domains contain 29 aspects. Five facets are only for people with HIV/AIDS: symptoms, social inclusion, forgiveness and blame, concerns about the future, and death and dying. In addition, there are two questions which assess the overall QoL: Question 1 which investigates individuals' perceptions of their QoL and Question 2 which evaluates the individuals' general health perceptions, totalling 31 items(10). The questions are individually scored on a Likert type scale, where 1 indicates low negative perceptions and 5 indicates high positive perceptions and the scores range from 4 to 20 points, reflecting the worst and the best QoL, respectively. It is designed to be selfadministered. Therefore, the researcher was with the respondents when they filled the questionnaire. The researcher also provided clarifications where necessary.

Procedure: The subjects were invited to participate in the study while they were waiting for consultation with an infectious disease specialist in the waiting room. All the subjects were informed about the purpose of the study. After obtaining the informed consent, they were filled the questionnaire. The data collection was carried out from September to November 2017 on Thursdays, the days of medical consultations, favouring the encounter with the largest number of registered clients.

Definition of operational Quality of Life: QoL is defined a low if the score between 4 and 9.9, intermediate if it is from 10 to 14.9 and high if the score 15 to 20 .

Ethical clearance: After explaining the research objectives, we obtained informed consent from each participant. Ethical permission to carry out this study was granted by the Department of Research and Community Engagement, the School of Nursing, Giri Satria Husada Wonogiri. The confidentiality of the data was ensured for all participants.

Data Analysis: The data were organized and coded in Excel spreadsheets and exported to the Statistical Package for the Social Sciences (SPSS) version 20.0 program. For the descriptive statistics, the absolute and relative frequency, mean, standard deviation, coefficient of variation, and minimum and maximum values were used (7). Quantitative data are presented as means \pm standard deviations (SD) while qualitative data are presented in terms of frequencies and proportions. A linear regression was used to evaluate factors that correlate PLWHAs' quality of life. In this study, the threshold of statistical significance was set at $p$ value less than 0.05 (16).

\section{RESULTS}

Table 1. describes the sociodemographic data of the participants. The mean age was $40.56 \pm 3.76$ years of the 39 participants: $59 \%$ were males and $41 \%$ were females. In terms of marital status, $18 \%$ of the participants were single, $59 \%$ were married and $23 \%$ were widows/widowers, $20.5 \%$ of the respondents had low education background and $79.5 \%$ of the respondents had high education background. In relation to HIV Status, $61.5 \%$ of the participants had no symptom and $38.5 \%$ showed symptoms. The mean of the time they were first diagnosed was $6.15 \pm 2.97$ years and the mean time period they were diagnosed with HIV was $6.41 \pm 3$ years.

DOI: http://dx.doi.org/10.4314/ejhs.v29i6.13 
Table 1. Participants'sociodemographic variables, medical status, coping mecahnism, symptom and time periode

\begin{tabular}{|c|c|c|c|}
\hline Variable & & $\mathrm{n}$ & $\%$ \\
\hline Age & $\mathrm{M} \pm \mathrm{SD}$ & $40.56 \pm 3.76$ & \\
\hline \multicolumn{4}{|l|}{ Gender } \\
\hline & Male & 23 & 59.0 \\
\hline & Female & 16 & 41.0 \\
\hline \multicolumn{4}{|l|}{ Marital status } \\
\hline & Single & 7 & 18 \\
\hline & Married & 23 & 59 \\
\hline & Widow/ Widower & 9 & 23 \\
\hline \multicolumn{4}{|l|}{ Education } \\
\hline & Low & 8 & 20.5 \\
\hline \multirow{3}{*}{ Sympton } & High & 31 & 79.5 \\
\hline & No Symptom & 24 & 61.5 \\
\hline & Show Symptoms & 15 & 38.5 \\
\hline First Diagnose & $\mathrm{M} \pm \mathrm{SD}$ & $6.15 \pm 2.97$ & \\
\hline Time Period (year) & $\mathrm{M} \pm \mathrm{SD}$ & $6.41 \pm 3.00$ & \\
\hline
\end{tabular}

Note: $\mathrm{M}=$ Mean; $\mathrm{SD}=$ Standard deviation.

The distribution of the parameters related to the WHOQOL-HIV BREF domains is presented in Table 2. The perception of intermediate QoL was revealed in all six domains investigated. Regarding the gross mean scores, it was observed that the highest ones were assigned to the social relationships domain (13.59), which evaluates the perception of the respondents regarding personal relationships, social support, social inclusion, and the psychological domain (13.31).

Table. 2. Distribution of the scores among people living with HIV/AIDS, according to the WHOQOL-HIV BREF*

\begin{tabular}{lcccccc}
\hline Domain & No. Items & Mean & SD & Variance & Min & Max \\
\hline Social Relationships & 4 & 13.59 & 3.912 & 15.301 & 7 & 20 \\
Psycological & 5 & 13.31 & 3.019 & 9.113 & 6 & 18 \\
Environment & 8 & 13.28 & 2.513 & 6.313 & 7 & 19 \\
Spiritual/Personal Beliefs & 4 & 13.15 & 4.215 & 17.765 & 6 & 20 \\
Physical & 4 & 13.10 & 3.127 & 9.779 & 7 & 20 \\
Level of Independent & 4 & 13.08 & 3.199 & 10.231 & 7 & 20 \\
\hline
\end{tabular}

*WHOQOL-HIV BREF: World Health Organization Quality of Life instrument-HIV BREF.

It assesses positive feelings, thinking, learning, memory and concentration, self-esteem, bodily image and appearance and negative feelings. Environment domain (13.28) is related to the perception of physical security, housing, finance, access to quality services, access to information, leisure, physical environment and transportation. Spiritual/personal beliefs domain (13.15), similar to personal beliefs, evaluates the perception regarding the feelings of forgiveness and blame, concerns about the future, and death and dying. The lowest means were assigned to the physical domain (13.10) which evaluates pain and discomfort, energy and fatigue, sexual activity, sleep and rest, and sensory function, and the level of independence domain (13.77). It assesses the perception of the respondents regarding their mobility, daily living activities, dependence on medication or treatment and ability to work. A regression model was used to examine factors related to PLWHAs'quality of life. The results are presented in table 3 - the

DOI: http://dx.doi.org/10.4314/ejhs.v29i6.13 
symptom of HIV associated with quality of life $(B$

$=7.611, \beta=0.362, t=2,046, p$ value $=0.049)$.

Table 3. Linear regression of factors Correlating PLWHAs' quality of life $(n=39)$.

\begin{tabular}{lccccc}
\hline \multirow{2}{*}{ Variable } & \multicolumn{4}{c}{ Quality of Life } \\
\cline { 2 - 5 } & $\mathrm{B}$ & Beta & $\mathrm{t}$ & $\mathrm{p}$-value & $95 \%$ CI \\
\hline Gender & -6.622 & 0.192 & $-1,098$ & 0.281 & $-18.923-5,680$ \\
Age & 0.072 & 0.045 & -0.245 & 0.808 & $-0.668-0.525$ \\
Marital Status & 3.774 & 0.142 & 0.759 & 0.454 & $-6.373-13.921$ \\
Education & 7.963 & 0.189 & 1,066 & 0.295 & $-7.276-23.201$ \\
Sympton & -7.611 & 0.362 & $-2,046$ & $0.049^{*}$ & $-15.198-0.024$ \\
First Diagnose & -0.086 & 0.012 & -0.033 & 0.974 & $-5.471-5.299$ \\
Time Period & -0.480 & 0.086 & -0.234 & 0.817 & $-4.673-3.712$ \\
\hline
\end{tabular}

Note. ${ }^{*} \mathrm{p}<0.05 . \mathrm{CI}=$ Confidence interval.

\section{DISCUSSION}

The mean age of the respondents was \pm 37.6 years. This result aligns with the current data from the Ministry of Health, indicating that HIV infections within the period of 2010 to 2014 mostly happened to individuals in the age group of 25-49 years(17). The early adulthood stage i.e. at 31 - 40 years of age are regarded as time to get new social life, that is to play a role as a husband or wife, parents, worker, or breadwinner(18). This indicates that in the productive age, risk factors that cause HIV / AIDS come from social factors, either internally or externally. Pressure from peers to do sexual intercouse, rape, sexual violence at young age generally lost price and feelings of control over their own lives, which then increases the risk of drug abuse and the sex life earlier and exposed to HIV(19).

In terms of gender, there were more male respondents than the female ones. This aligns with the research conducted by Hardiansyah on the quality of life of people living with HIV and AIDS in Makassar based on gender, which indicated that most of the respondents were males $(71.4 \%)$ and the female respondents were only $6(28.6 \%)(20)$. The difference in terms of the number of proportions did not affect the quality of life of PLWHA as indicated by the results of the 6 domains. The quality of life of PLWHA, both men and women, was in the intermediate category. This study contradict previous studies that show differences in the assessment of QoL between genders (21),(22).

In terms of marital status, most of the respondents are married. This supports the previous research on factors which affect the quality of life of people with HIV/AIDS (PLWHA) at the Peer Support Foundation Group Care in Makassar City in 2014, From the statistical analysis performed using ANOVA test, the result $p(0.208)>0.05$ was obtained, showing no significant differences (23). Based on the level of education, the respondents were in the high education category.

The result of quality of life assessment of PLWHA with WHOQOL-HIV BREF showed that social domain got the highest score in this study. Based on the deep question how satisfied PLWHA with their personal/social relationship, most of them answered satisfying. The results of this study align with previous research on factors affecting the quality of life (23). This result contradicts a previous study showing that half of the respondents had a substantial impact on social relationships with relatives and/or friends (24).

Psychological domain got the second highest score. This is because PLWHA can enjoy their life like other normal people who do not have HIV/AIDS. With regard to the way they enjoy life, most of the PLWHA answered that they follow Peer Support Group (PSG); they meet, communicate, open each other, and exchange information about the disease. Based on the

DOI: http://dx.doi.org/10.4314/ejhs.v29i6.13 
question of how often they have negative feelings such as feeling blue (loneliness), despair, anxiety, and depression, the majority of the respondents answered that they rarely have such feelings, because PSG plays an important role in building the self-concept of PLWHA in developing confidence, changing the perception and behaviour of PLWHA through counselling and study club. They obtained a lot of experience and care support from fellow PLWHA and counsellor. They thought that HIV/AIDS is not the end of their life. There are many things that can be done despite the positive diagnosis. This is what makes people living with HIV do not feel despair, worry, depression, loneliness, and try to commit suicide because they gets support from the significant other. The results of this study contradict previous research in terms of psychology as 16 or $76.2 \%$ fall into the category of poor quality of life for the question of how often to enjoy life and how often concentrate on only 1 respondent $(4.8 \%)$ who answered the category very often (20).

Based on the question how safe PLWHA in their environment, most of respondent answered in the medium status. PLWHA has no difficulty to cooperate with the community. PLWHAs can work together well in their place of work without any discrimination from other colleagues, although the identities of those people living with HIV/AIDS have been revealed, they can still get along and adapt easily with the community, by maintaining their behaviour of good behaviour. The results of this study contradict with previous study that people only know about HIV and AIDS is limited to infectious diseases and harmful sufferers. However, most people still do not understand correctly the factors of spread and how to overcome them. The existence of this lack of understanding leads to overprotective attitude towards people living with HIV (20).

The fourth highest score of QoL from this study is spiritual/personal beliefs domain; PLWHA felt that their life is less. They are often worried about the future especially with death. If they are worried about their future, they tend to worship or get closer to God according to their religion. This activity can affect the quality of life of PLWHA who will feel calmer and not worried about the future, especially with death. Spirituality and religion have traditionally played a major role and have contributed to their quality of life (QOL) and are also very important for PLWHA (25).

Physical and level of independent domain obtained the lowest score because there are some respondents who have not been able to accept the fact that they have HIV and sometimes do not take ARVs regularly (23). Based on the assessment results from the level of independence domains, most respondents have a moderate QoL. The previous research mentioned that the level of independence of patients in the association is very bad that is equal to $38.1 \%$ and only $4.8 \%$ of respondents have very high social skills (20).

The average of quality of life of PLWHA based on the six domains is intermediate. The analysis of the gross mean showed that the better assessments of QoL in the group were associated with the perceptions of the respondents regarding personal relationships, and social support. Meanwhile, the lower scores indicate that this relationship may have a connection with the issues surrounding the use of antiretroviral therapy and its impact on life in general (level of independence domain).

The result of regression test shows that symptoms of HIV have a correlation with QoL PLWHA. This result is similar to that of a previous study describing asymptomatic respondents who enjoyed better QoL in the domain of physical and level independence and had better perception regarding QoL and general health than the respondents of symptomatic (26)(27)(28)(29). The explanation of this finding is that those who are sick are burdened with physical symptoms of the disease (30).

Despite the results, the study still has some limitations. The research participants were recruited from a reference service which tends to present individual samples with better living and health conditions. This aspect might affect the overestimation of Qol scores which may not reflect the Indonesian population in general. However, the scores explain QoL and its relationship with socioeconomic aspects of PLWHA with regard to the epidemic of HIV in the Indonesian population.

Furthermore, healthcare providers should increase provider-initiated testing and counselling (PITC) to contracting group, high risk group,

DOI: http://x.doi.org/10.4314/ejhs.v29i6.13 
susceptible group, and the community. People living with human immunodeficiency virus/AIDS (PLWHA) are recommended to join peer support group (PSG) actively so that they can improve their quality of life.

\section{ACKNOWLEDMENTS}

The author would like to thank Akademi Keperawatan Giri Satria Husada Wonogiri and Faculty of Nursing, University of Jember.

\section{REFERENCES}

1. Gastein F. Well-being in Europe " at the 14th European Health Designing the road to better health 1948 WHO definition of health 1948 WHO definition of health. World Heal Organ. 2011;(October):1-16.

2. Maracy MR, Mostafaei S, Moghoofei M, Mansourian M. Impact of HIV risk factors on survival in Iranian HIV-infected patients: A Bayesian approach to retrospective cohort. HIV AIDS Rev [Internet]. 2017;16(2):100-6. Available from: http://www.embase.com/search/results?suba ction $=$ viewrecord \& from $=$ export \&id $=\mathrm{L} 6222$ 12561\%0Ahttp://dx.doi.org/10.5114/hivar.2 017.68117

3. Pozniak A. Quality of life in chronic HIV infection. Lancet HIV [Internet]. 2014;1(1):e6-7. Available from: http://dx.doi.org/10.1016/S23523018(14)70003-7

4. Fatmawati, Widodo GG, Wakhid A. Kualitas Hidup Orang Dengan HIV/AIDS (ODHA) Berdasarkan Quality Of Life (World Health Organisation Quality Of Life - Bref) Di Kota Semarang (Quality Of Life Of People With HIV / AIDS (PLWHA) Based On The Quality Of Life (World Health Organization Of Life - Bref) In The City Of Semarang). Vol. 38. Stikes Ngudi Waluyo Ungaran Semarang; 2016..

5. Karkashadze E, Gates MA, Chkhartishvili N, DeHovitz J, Tsertsvadze T. Assessment of quality of life in people living with HIV in Georgia. Int J STD AIDS. 2017;28(7):672-8.

6. Sánchez Sánchez E. Relación entre el consumo de fructosa y el aumento de la obesidad. Metas de Enfermería [Internet]. 2016;19(9):14-9. Available from: https://www.medes.com/Public/ResumePub lication. aspx?idmedes $=118700$

7. Hipolito RL, De Oliveira DC, Da Costa TL, Marques SC, Pereira ER, Gomes AMT. Quality of life of people living with HIV/AIDS: Temporal, socio-demographic and perceived health relationship. Rev Lat Am Enfermagem. 2017;25.

8. Surur AS, Teni FS, Wale W, Ayalew Y, Tesfaye B. Health related quality of life of HIV/AIDS patients on highly active antiretroviral therapy at a university referral hospital in Ethiopia. BMC Health Serv Res. 2017;17(1):1-8.

9. Kumar A, Girish H, Nawaz A, Balu P, Kumar B. Determinants of quality of life among people living with HIV/AIDS: A cross sectional study in central Karnataka, India. Int $J$ Med Sci Public Heal. 2014;3(11):1413.

10. WHO. World Health Orgaization. Division Of Mental Health And Prevention Of Substance Abuse: WHOQOL User Manual. 2012;1-106.

11. UNAIDS. Global AIDS Monitoring 2017. UNAIDS. 2017.

12. Tesfaye M, Olsen MF, Medhin G, Friis H, Hanlon C, Holm L. Adaptation and validation of the short version WHOQOLHIV in Ethiopia. Int $J$ Ment Health Syst. 2016;10(1):1-10.

13. Hsiung PC, Fang CT, Wu CH, Sheng WH, Chen SC, Wang J Der, et al. Validation of the WHOQOL-HIV BREF among HIVinfected patients in Taiwan. AIDS Care Psychol Socio-Medical Asp AIDS/HIV. 2011;23(8):1035-42.

14. Salehi M, Niroumand S, Erfanian M, Sajjadi $\mathrm{R}$, Dadgarmoghaddam M. Validation of Persian version of WHOQOL-HIV BREF questionnaire in Islamic Republic of Iran. East Mediterr Heal J. 2016;22(9):647-53.

15. Zubairi D; Murdani A; Nanda N; Muhammad H; Shatri. Validity and reability test of Indonesian version of world health

DOI: http://dx.doi.org/10.4314/ejhs.v29i6.13 
the quality of life patients with HIV / AIDS. J Penyakit Dalam Indones. 2017;4(3):1167.

16. Susanti IA, Mahardita NGP, Alfianto R, Sujana IMIWC, Susanto T. Social stigma, adherence to medication and motivation for healing : A cross-sectional study of leprosy patients at Jember Public Health Center, Indonesia. $J$ Taibah Univ Med Sci. 2018;13(1):97-102.

17. RI KK. Pusat Data Dan Informasi kementrian kesehatan RI (Situasi dan analisis HIV/AIDS)( Indonesian Ministry of Health Data and Information Center (HIV / AIDS situation and analysis)) [Internet]. 2016. Available from: WWW.depkes.go.id/pustadin

18. Pieter, H.Z. \& Lubis NL. Pengantar Psikologi Dalam Keperawatan (Introduction to Psychology in Nursing). Jakarta : Kencana; 2010.

19. Noviana N. Kesehatan Reproduksi dan HIV/AIDS (Reproductive Health and HIV / AIDS) Jakarta : CV Trans Info; 2013.

20. Amiruddin R, Sidik Arsyad Bagian Epidemiologi Fakultas Kesehatan Masyarakat Universitas Hasanuddin D. Kualitas Hidup Orang Dengan HIV Dan AIDS Di Kota Makassar (Quality of Life for People with HIV and AIDS in Makassar) 2014;1-11. Available from: http://repository.unhas.ac.id/bitstream/hand le/123456789/10736/HARDIANSYAH K11110602.pdf?sequence $=1$

21. OD. CT. Quality of life of people with human immunodeficiency virus and interiorization: multidimensional assessment. $J$ Nurs UFPE. 2013;7(10):5866-75.

22. Pereira, M. \& Canavarro MC. Gender and Age Differences in Quality of Life and the Impact of Psychopathological Symptoms Among HIV-Infected Patients. AIDS Behav. 2011;15(8):1857-1869.

23. Magfirah Amir Makkau, Muhammad Ikhsan R. Faktor Yang Mempengaruhi Kualitas Hidup Orang Dengan HIV dan AIDS ( ODHA ) Di Yayasan Peduli Kelompok Dukungan Sebaya ( YPKDS )
Kota Makassar (Factors Affecting the Quality of Life of People Living with HIV and AIDS (PLWHA) at the Foundation of Care for Peer Support Groups (YPKDS) Makassar). :670. Available from: http://repository.unhas.ac.id/bitstream/hand le/123456789/12778/ABSTRAK.pdf;seque nce $=1$

24. Zhang Y, Zhang X, Aleong TH, Fullerthomson E. Impact of HIV / AIDS on Social Relationships in Rural China. Open AIDS J. 2011;5:67-73.

25. Williams L, Larkin R. African-American women with HIV/AIDS. Hum Behav Soc Environ from an African-American Perspect Second Ed. 2013;6(2):479-500.

26. Razera F, Ferreira J, Bonamigo RR. Factors associated with health-related quality-oflife in HIV-infected Brazilians. Int J STD AIDS. 2008;19(8):519-23.

27. Kovačević SB, Vurušić T, Duvančić K, Maček M. Quality of life of HIV-infected persons in Croatia. Coll Antropol. 2006;30(SUPPL. 2):79-84.

28. Nojomi M, Anbary K, Ranjbar M. Healthrelated quality of life in patients with HIV/AIDS. Arch Iran Med. 2008;11(6):608-12.

29. Rai Y, Dutta T, Gulati AK. Quality of life of HIV-infected people across different stages of infection. $\mathrm{J}$ Happiness Stud. 2010;11(1):61-9.

30. Mrus JM, Leonard AC, Yi MS, Sherman SN, Fultz SL, Justice AC, et al. Healthrelated quality of life in veterans and nonveterans with HIV/AIDS. $J$ Gen Intern Med. 2006;21(SUPPL. 5):39-47.

DOI: http://dx.doi.org/10.4314/ejhs.v29i6.13 